tested by an appeal to facts, and it will be our duty in the course of our investigations to examine all the data which have been adduced in their support. I bave referred to them on this occasion merely to show you that above and beyond the more or less obvious interpretation of geological phenomena, larger questions arise, the consideration of which demands not only laborious and far-extended observation, but must call into exercise all the varied powers of the human mind.

In the initial stages of our geological investigations we are occupied in detecting the more apparent resemblances and correspondences between the present and the past. We readily discover in sedimentary strata the evidence of their accumula. tion by the action of water, nor do we experience much difficulty in discovering the igneous origin of many rock-masses in regions now far removed from scenes of volcanic activity. But each observation we make and every well-founded correspondence we establish between the present and the past leads on to larger and larger deductions, until, as in the case of our granitic dykes and veins, we eventual'y find that geological investigations frequently increase our acquaintance with forces now in action and give us some insight in to the hidden operations of nature. It is not indeed too much to say that in many cases our knowledge of such operations is derived in large measure from a study of the effects produced by the work of nature in past ages. The examination, for example, of the fragmentary relics of ancient volcanoes, in this and other countries where volcanic action has long been extinct, has enabled us to picture to ourselves many details of the structure of those interior and basement parts of a volcanic mountain, which otherwise must ever have remained unknown. The long-continued action of the agents of denudation has often removed those superficial rock-masses which gather around volcanic orifices, so as to lay bare, as in a dissection, the interior and basal portions-showing us the fractured and baked strata through which the heated gases, molten matter, and loose ejectamenta were erupted, and the dykes and veins of crystalline rock which were injected into the cracks and fissures of the shattered strata. Nay, a study of those vast masses and sheets of granitic, gneissose, and schistose rocks, of which large portions of the Scottish Highlands, Scandinavia, and other countries are composed, induces the belief that these rocks originally existed as ordinary sedimentary strata, and that their present crystalline condition has been assumed at a time when they were deeply buried underneath other and of course younger strata. And thus we have hints given us as to what may be taking place now throughout extensive areas underneath the surface of the earth, where other sandstones and shales may be undergoing a gradual metamorphism and conversion into crystalline rocks.

(To be continued.)

\section{THE SENSES OF BEES}

$A T$ the meeting of the Linnean Society on Thursday last, Sir John Lubbock read an account of his further observations on the habits of insects, made during the past year. The two queen ants which have lived with him since 1874 , and which are now, therefore, no less than eight years old, are still alive, and laid eggs last summer as usual. His oldest workers are seven years old. Dr. Muiller, in a recent review, had courteously criticised his experiments on the colour sense of bees, but Sir John I ubbock pointed out that he had anticipated the objections suggested by Dr. Müller, and had guarded against the supposed source of error. The difference was, moreover, not one of principle, nor does Dr. Muiller question the main conclusions arrived at, or doubt the preference of bees for blue, which indeed is strongly indicated by his own observations on flowers. Sir John also recorded some further experiments with a reference to the power of hearing. Some bees were trained to come to honey which was placed on a musical box on the lawn close to a window. The musical box was kept going for several hours a day for a fortnight. It was then brought into the house and placed out of sight, but at the open window and only about seven yards from where it had been before. The bees, however, did not find the honey, though when it was once shown them, they came to it readily enough. Other experiments with a microphone were without results. Every one knows that bees when swarming are popularly, and have been ever since the time of Aristotle, supposed to be influenced by clanging kettles, \&c. Experienced apiarists are now disposed to doubt whether the noise has really any effect, but $\mathrm{Sir}$ John suggests that even if it has, with reference to which he expressed no opinion, it is possible that what the bees hear are not the loud low sounds, but the higher overtones at the verge of, or beyond our range of hearing. As regards the industry of wasps, he timed a bee and a wasp, for each of which he provided a store of honey, and he found that the wasp began earlier in the morning (at 4 a.m.), worked on later in the day. He did not, however, quote this as proving greater industry on the part of the wasp, as it might be that they are less sensitive to cold. Moreover, though the bee's proboscis is admirably adapted to extract honey from tubular flowers, when the honey is exposed, as in this case, the wasp appears able to swallow it more rapidly. This particular wasp began work at four in the morning, and went on without any rest or intermission till a quarter to eight in the evening, during which time she paid Sir John I 6 visits.

\section{INVERTEBRATE CASTS VERSUS ALGAE IN PALAEOZOIC STRATA}

THE distinguished Swedish geologist, Dr. A. Nathorst, having made numerous experiments, has come to the conclusion that invertebrate animals, when creeping over a soft seabottom, will leave imprints which are identical with the markings which have hitherto been considered those of fossil Algæ. If these Algx are examined, it will be found, he states, that the appearance of a great many of them indicate that they have not been organisms at all, but formed in some mechanical way, and that analogous forms may even be found in existing species.

Dr. Nathorst considers that with the exception of three groups, the greatest number of Algæ enumerated in Mr. Schimper-Zittel's work on Palæontology as "undefined," are merely imprints of invertebrate animals.

Some time ago Prof. Martens of Berlin demonstrated that ichthyological members of the genus Periophtalmus which he had watched on the coast of Borneo when creeping over a clay bottom, left regular and defined impressions from their body and fins on the surface which would, if preserved, easily be mistaken for cryptogamic fossils, and in a paper on casts of Medusa in the Cambrian strata of Sweden, Dr. Nathorst further shows that the so-called Eophyton spatangopsis, \&c., which have been considered imprints of certain zoophytes and mollusks, are traces of Medusæ. These "fossils" are, according to his theory, either traces which Medusæ leave when carried by the motion of the water over a soft bottom (Eophyton), or imprints of their belly and adjacent organs when at rest. He further shows, that a more solid kind of Medusæ than the common have left traces in the calcareous slate of Central Germany, which makes it possible, in some measure, to define their relation to existing species.

Hitherto, Medusæ have only been traced back to the Jurassic period, but Dr. Nathorst shows that these organisms have existed from at least Cambrian times. The imprints which the lower organisms leave on mud or sand vary in appearance with the creeping or swimming habits of the animals, as well as with the nature of the bottom, whilst it is particularly interesting to note that certain worms produce imprints and vermiculated holes, which are exactly like the radiant Algæ, and which would not be supposed to be the work of invertebrata, if their formation had not been clearly demonstrated.

In connection herewith it should be mentioned, that imprints may also be made in a soft sea-bottom by stones, which are carried along with the tide by floating sea-weeds, regarding which observations have recently been made by the Scottish naturalist, Mr. Symington Grieve.

C. S.

\section{RIOLOGY IN ITALY1}

IN welcoming the appearance of this new journal under the editorship of Prof. Emery, of Bologna, and Prof. Mosso of Turin, it may not be amiss to mention briefly the programme of its originators. They will endeavour each year to give a classified list of all works published in Italy on biology, in its widest sense. The list for I88I, with an index of the names of authors, appears in volume $\mathrm{I}$. They will try and bring together and illustrate original memoirs on subjects which treat of life in every form. In addition to these there will from time to time appear résumés and notices of memoirs appearing in other Italian journals; and as far as practicable the résumés will be drawn up by the authors of the papers abstracted. The archives will be

I "Archives Italiennes de Biologie," tome i., 1882. Tome ii. fasc. i., 
published in French, "because this language is, without the possibility of contradiction, that one the most universally known among all the living languages."

Most heartily do we echo the following words of the editors :-

"L'Italie a été jadis le berceau de la renaissance des arts et des sciences. D'autres nations nous ont depuis lors dépassés; mais l'unité de la patrie est venue rallumer le foyer du travail, et donner un nouvel essor aux études scientifiques, dont nous constatons chaque année les rapides progrès. Les travaux qui verront le jour dans les Archives Italiennes de Biologie seront, pour notre pays, nous l'espérons, un nouveau titre à l'estime de tous ceux qui prennent intérêt à l'avancement des sciences de la vie."

Among the chief articles in volume I. are the following :-Physiology: On a new element in the blood of mammals, and its importance in thrombosis and in coagulation; on the production of the red globules in extra uterine life; and on small blood discs in mammals, by G. Bizzozero; on the reproduction of the marrow in long bones; and on the regeneration of articular extremities in sub-capsular periosteal resections, by D. Bajardi ; on the hæmatopoetic functions, and on the complete reproduction of the spleen, by G. Tizzoni; on hepatic glycogenesis, by $\mathrm{Ph}$. Lussana; on the functions of the bladder, by A. Mosso and A. Pellacani; on the structure of the spinal coril, by J. B. Laura; on varietes in the cerebral circumvolutions in man, by C. Giacomini; critical experimental study of the cortical motor centres, by A. Marcacci ; on the caducousness of the ovarial parenchyma and its total rehabilitation, by J. Paladino; origin of the olfactory tract, \&c., in mammals, by C. Golgi. Pathology: Contribution to the pathology of the muscular tissue, by E. Perroncito; contribution to the study of endocartitis, by V. CoIomiatti ; contribution to the subject of intestinal cysts, by $\mathrm{H}$. Marchiafava; on the discovery of the specific ferment of malaria in the blood, by the Editors. Zoology: On the origin of the central nervous system in annelids, by N. Kleinenberg, of Messina; on the nervous system and sense organs of Spharoma serratum, by J. Bellonci; on a new genus (Distaplia) of Synascidians, by A. Della Valle; on the metamorphoses of some Insecticole Acari, by Ant. Berlese. Botany: On the action of ether and chloroform on the sensitive organs of plants, oy C. Cugini; on the active principle of Adonis vernalis, by V. Cervello ; contribution to the study of the genus Cora, Fr., by $O$. Mattirolo ; researches on the anatomy of leaves, by $I$. Briosi.

Vol. ii. part I, contains : On the early phenomena of development in Salpa, by F. Todaro ; on the anatomy of the compound Ascidians; and on budding in the Didemnidæ and Botryllidæ, and on the enterocœetlic type in the Ascidia, by A. Della Vallee; polymorphism and parthenogenesis in some Acari (Gamasidæ), by A. Berlese; on an unobserved organ in some vegetable embryos, by S. Briosi; experimental study of the cortical motor centres, by A. Marcacci; experiments on the formation of uric acid, by $\mathrm{J}$. Colasanti ; on the action of oxygenated water $\left(\mathrm{H}^{2} \mathrm{O}^{2}\right)$ on animal organisms, by $\mathrm{J}$. Colasanti and S. Capranica; on the toxic action of human saliva, by $\mathbf{L}$. Griffini.

\section{UNIVERSITY AND EDUCATIONAL INTELLIGENCE}

OXFORD. - In addition to the Scholarships in Natural Science offered by Balliol and Christ Church this term, of which details have been published in NATURE, a scholarship in Natural Science will be offered for competition next term by Queen's College. Papers will be set in Chemistry, Physics, and Biology. No candidate will be expected to offer more than two of these subjects. Candidates are requested to signify their intention of standing by letter to the Provost, not later than February I, and to state the subjects they propose to offer.

The Natural Science Scholarship at Exeter College has not been awarded. Mr. H. O. Minty, of the Royal College of Science, Dublin, has been elected to an Exhibition. Mr. Minty was proxime at the late examination for the Trinity Natural Science Scholarship, but being over the statutable age, was not eligible for a scholarship at Exeter College.

CAMbridge.-Prof. C. C. Babington, F.R.S., Professor of Botany in the University of Cambridge, has been elected to a Professorial Fellowship at St. John's College. Prof. W. J. Sollas, F.G.S , Professor of Geology at University College, Bristol, has also been elected Fellow of St. John's College.
THE number of students at Dorpat University is vastly increasing from year to year. While in. 1867 the number was only 573 , it reached 728 in 1872,858 in 1877 , 1105 in 1880 , and now stands at 1367 students.

\section{SCIENTIFIC SERIALS}

Fournal of the Royal Microscopical Society for August, 1882, contains: On some micro-organisms from rain-water, ice, and hail, by Dr. R. L. Maddox.-On the relation of aperture and power in the microscope, by Prof Abbe.-Description of a simple plan of imbedding tissues for microtome cutting in semipulped unglazed printing paper, by B. W. M. Richardson.Note on Rev. G. L. Mills' paper on diatoms in Peruvian guano, by $F$. Kitton, - The usual summary of current researches relating to zoology and botany (principally invertebrate and cryptogamia), microscopy, \&c., including original communications from Fellows and others.-Proceedings of the Society.

The same journal for October, I882, contains: On plant crystals, by Dr. Aser Poli (plate 6), and the summary of current researches relating to zoology and botany (principally invertebrata and cryptogamia), microscopy, \&c., including original communications from Fellows and others.

The Ouarterly Fournal of Microscopical Science, No. 87, for July, 1882, contains :- Note on the formation of fibrine, by Mrs. Ernest Hart (plate 2I).-On the genesis of the egg in Triton, by T. Iwakawa (plates 22-24). - On the germination and embryogeny of Gnetum gnemon, by F. O. Bower (plate 25).The organ of Jacobson in the dog, by Dr. E. Klein (plate 26). -On Saprolegnia in relation to the salmon disease, by Prot. Huxley.-Notes on certain methods of cutting and mounting microscopical sections, and on the central duct of the Nephridium of the leech.

No. 88, for October, 1882 , contains : On the development of Ostrea edulis, by Dr. R. Horst (plate 27). - The morphology and life-history of a tropical Pyrenomycete, by $\mathrm{H}$. Marshall Ward (plates 28 and 29). - The thread cells and epidermis of Myxine, by R. Blomfield (plate 30).-The eye of Spondylus, by Sydney J. Hickson. - Note on open communication between the cells in the pulvinus of Mimosa pudica, by W. Gardiner.-Notes on the development of Mollusca, by Prof. Hadion.-Note on Echinoderm morphology, by P. Herbert Carpenter (woodcuts). - On the vertebration of the tail of Appendicularix, by Prof. Lankester.Notes on the structure of Seriatopora, Pocillopora, Corallium, and Tubipora, by Prof. Moseley (woodcut). - Note on pacinian corpuscles, by Dr. V. Harris.-Reviews of Strasburger's structure and growth of the cell wall, and of Bergh's restarches on the cilio-fiagellata.

Proceeaings of the Royal Society of Tasmania for 1880 , contains:-Algæ of the New Hebrides, by Dr. Sonder, contains new species of Sarcodia, Caulerpa, and Chætomorpha.-On some Australian slugs, by Prof. R. Tate.-On the Unios of the Launceston Tertiary bain, by R. Etheridge, jun. (with a plate). - On a fossil helix, by R. M. Johnston (with a plate). -The lichens of Queensland, by F. M. Bailey.-On some fossil leaves and fruits, by Dr. C. E. Bernard.-On some introduced plants, by Rev. G. E. Tenison Woods.-On some new species of fish, by R. M. Johnston.-On oyster culture, by Capt. Stanley, R.N.

Bulletin de la Soc. Imp. des Naturalistes de Moscou, I881, No. 4, contains : On new species of European Mints, by M. Grandoger.-On the Amphibia and Reptiles of Greece, by Dr. J. v. Bedriaga.-On new species of Hemiptera from the Aral and Caspian districts, by V. Jakovlev (in Russian, but the diagnoses of the new genera and species are given in German). - Catalogue of the Lepidoptera of the Moscow district, by L. Albrecht (Supplements Dr. E. Assmus's catalogue of 1858 , and raising the number of species from 675 to 1172 . - On new Lepidoptera from the Amur Land, by H. Christoph.-Meteorological observations (Moscow) for 188I, by J. Weinberg.

\section{SOCIETIES AND ACADEMIES LONDON}

Chemical Society, November 2.-F. A. Abel, F.R.S., vice-president, in the chair.- It was announced that a ballot for the election of Fellows would take place at the next meeting (November 16). - The following papers were read:-On dihy- 